\title{
EFFECTS OF TAUTOMYCIN, A PROTEIN PHOSPHATASE INHIBITOR, ON RECYCLING OF MAMMALIAN CELL SURFACE MOLECULES
}

\author{
Tomohiro Kurisaki, JUnJi MaGaE*,a, Kiyoshi IsOno ${ }^{b}$, \\ KaZUO NAGaI a and MAKaRI YamaSAKI \\ Department of Agricultural Chemistry, The University of Tokyo, \\ 1-1-1 Yayoi, Bunkyo-ku, Tokyo 113, Japan \\ aDepartment of Bioengineering, Tokyo Institute of Technology, \\ Nagatsuta, Midori-ku, Yokohama 227, Japan \\ ${ }^{b}$ RIKEN, The Institute of Physical and Chemical Research, \\ Wako-shi, Saitama 351-01, Japan
}

(Received for publication September 5, 1991)

\begin{abstract}
The effects of tautomycin, a protein phosphatase inhibitor, on recycling of cell surface molecules were studied with transferrin receptor (TFR) of human myeloid leukemia K562 cells and with CD4 of murine thymocytes. Tautomycin increased expression of TFR of K562 cells whereas phorbol dibutylate $(\mathrm{PDBu})$ decreased it. Tautomycin inhibited PDBu-induced down-regulation of CD4 although it did not induce up-regulation. Okadaic acid also inhibited down-regulation of CD4 which was induced by PDBu. The results suggest that certain inhibitors of protein phosphatases preferentially inhibit endocytosis of cell surface molecules.
\end{abstract}

Tautomycin is an antifungal antibiotic isolated from Streptomyces spiroverticillatus ${ }^{1,2)}$. Tautomycin induced blebs on the surface of human myeloid leukemia K562 cells ${ }^{3)}$. The morphological change, named bleb formation, was also induced by phorbol dibutylate $(\mathrm{PDBu})^{3)}$, cytochalasin $\mathrm{D}(\mathrm{CyD})$ and okadaic acid $(\mathrm{OA})^{4}$ suggesting that modulation of actin filament network and/or protein phosphorylation is involved in tautomycin-induced bleb formation ${ }^{4)}$. Further studies on tautomycin revealed that tautomycin is a novel inhibitor of protein phosphatases and that the specificity of tautomycin to the enzymes was distinct from known inhibitors of protein phosphatases ${ }^{5,6}$. Cytoskeleton and protein phosphorylation are also involved in recycling of cell surface receptors for transferrin and epidermal growth factor (EGF) ${ }^{7,8)}$. In fact, phorbol esters are known to affect expression of a number of important regulatory molecules on cell surface including the receptors for $\mathrm{EGF}^{8)}$ and transferrin ${ }^{9)}$ and $\mathrm{CD} 4^{10)}$. In the present paper, we studied the effects of tautomycin on phorbol ester-induced down-regulation of transferrin receptor (TFR), on K562 cells, and the effect of CD4 on murine thymocytes.

\section{Materials and Methods}

\section{Chemicals}

Tautomycin was isolated as described by CHENG et al. ${ }^{1)}$ Staurosporine was also isolated from the culture broth of an actinomycetes. Okadaic acid and dinophysistoxin-1 were kindly donated by Dr. H. FuJiki (National Cancer Center Research Institute, Japan). Cytochalasin D and PDBu were purchased from Sigma Chem. H-7, H-8 and W-7 were purchased from Seikagaku Kogyo Co., Ltd. Japan. K252a and KT5926 were kindly gifted by Dr. H. KASE (Kyowa Hakko Kogyo Co., Ltd.).

\section{Cell Culture}

Cells were cultured in RPMI-1640 medium supplemented with $10 \%$ fetal calf serum (FCS), $0.05 \mathrm{~mm}$ 2-mercaptoethanol, $50 \mathrm{mg} /$ liter kanamycin and $8 \mathrm{mg} /$ liter tylosin at $37^{\circ} \mathrm{C}$ in $5 \% \mathrm{CO}_{2}$ atmosphere. 
Analysis of Surface Molecules

Expression of surface molecules was quantitated using a flow cytometer (Epics C, Coulter Electrics, Inc. Healeah, Florida, U.S.A.). For analysis of TFR, K562 cells were treated with drugs at $37^{\circ} \mathrm{C}$ and were washed twice with cold buffer A (HANK's balanced salt solution containing $0.2 \%$ sodium azide and $2 \%$ FCS). Then the cells were incubated with mouse anti-human TFR antibody (final dilution $1: 20$; Becton Dickinson) at $4^{\circ} \mathrm{C}$ for 45 minutes. After being washed for three times with buffer $\mathrm{A}$, the cells were incubated with FITC-conjugated anti-mouse immunoglobulin antibody (final dilution $1: 20$; Cappel) at $4^{\circ} \mathrm{C}$ for an additional 45 minutes. For analysis of $\mathrm{CD} 4$, thymocytes from $\mathrm{C} 3 \mathrm{H}$ mice (Nippon Charles River Co., Ltd.) were cultured with drugs at $37^{\circ} \mathrm{C}$ and were washed twice with cold buffer $\mathrm{A}$. Then the cells were incubated with phycoerithrin-conjugated anti-L3T4 antibody (final dilution $1: 10$; Becton Dickinson) at $4^{\circ} \mathrm{C}$ for 45 minutes.

\section{Results}

\section{Effects of Tautomycin on Transferrin Receptor}

Effects of tautomycin on TFR of K 562 cells were analyzed by a flow cytometer using indirect fluorescent antibody technique (Fig. 1). As reported previously ${ }^{10 \sim 12)}$, phorbol ester which is an activator of protein kinase $\mathrm{C}(\mathrm{PKC})^{13)}$ induced down-regulation of TFR. An inhibitor of protein kinase, staurosporine ${ }^{14)}$, inhibited the PDBu-induced down-regulation. On the contrary, tautomycin increased surface expression of TFR, and the expression was not inhibited by staurosporine. Simultaneous treatment of K562 cells with tautomycin and PDBu resulted in enhancement of up-regulation of TFR.

\section{Effects of Tautomycin on CD4 on Murine Thymocytes}

As has been reported ${ }^{15 \sim 17)}$, PDBu induced down-regulation of CD4 on murine thymocytes (Fig. 2).

Fig. 1. Effects of tautomycin on PDBu-induced down-regulation of transferrin receptor.

K562 cells were cultured for I hour in the absence (A, C, E, G), or the presence of staurosporine (100 ng/ml; B, D, F, H). PDBu $(1 \mu \mathrm{g} / \mathrm{ml} ; \mathrm{C}, \mathrm{D})$, tautomycin $(30 \mu \mathrm{g} / \mathrm{ml} ; \mathrm{E}, \mathrm{F})$ or tautomycin and $\mathrm{PDBu}$ $(\mathrm{G}, \mathrm{H})$ were added simultaneously.

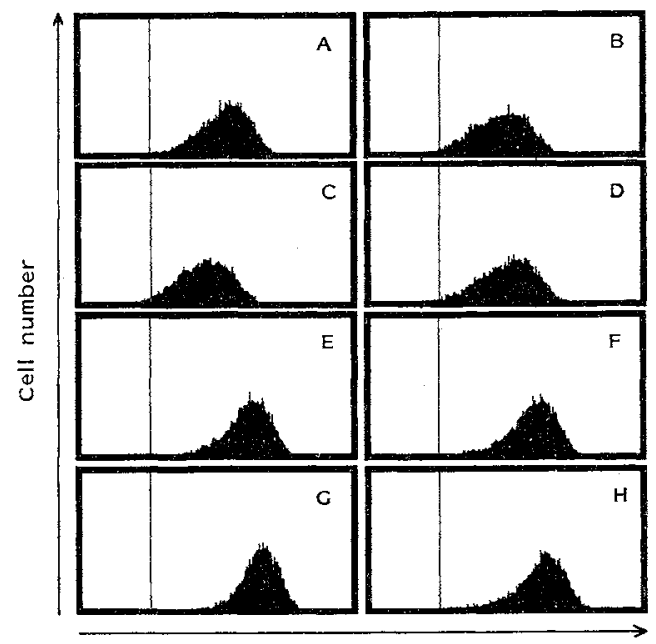

log green fluorescence

Expression of TFR was determined as described in Materials and Methods.
Fig. 2. Effects of tautomycin on PDBu-induced down-regulation of CD4.

Thymocytes were cultured for 1 hour in the absence $(A, C, E, G)$ or the presence of PDBu $(100 \mathrm{ng} / \mathrm{mI}$; B, $\mathrm{D}, \mathrm{F}, \mathrm{H}$ ). Staurosporine (100 ng/ml; C, D), tautomycin $(30 \mu \mathrm{g} / \mathrm{ml} ; \mathrm{E}, \mathrm{F})$ or both of staurosporine and tautomycin $(\mathrm{G}, \mathrm{H})$ were added to the culture.

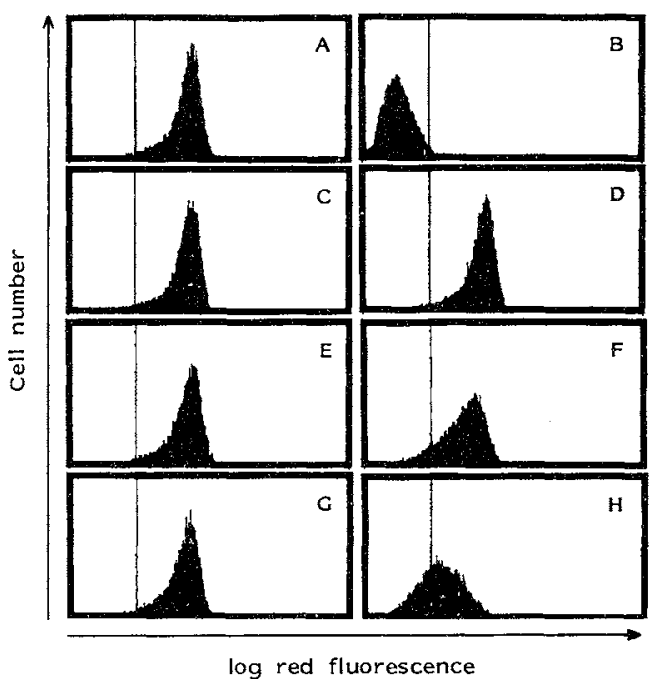

Expression of CD4 was determined as described in Materials and Methods. 
Although tautomycin alone had no effect on expression of CD4, tautomycin as well as staurosporine inhibited PDBu-induced down-regulation of CD4. Only partial inhibition was observed when the cells were treated with tautomycin and staurosporine simultaneously.

\section{Effects of Tautomycin on Re-expression of CD4}

To determine whether tautomycin or staurosporine can induce re-expression of CD4, thymocytes, CD4 of which had disappeared by the treatment with PDBu for 1 hour, were washed and cultured in the absence of PDBu for 1 hour (Fig. 3). The second culture without PDBu allowed partial re-expression of CD4. Addition of tautomycin or staurosporine during the period of second culture had no effect on the expression of $\mathrm{CD} 4$. The results demonstrate that tautomycin and staurosporine inhibit down-regulation but do not affect re-expression of CD4.

Effects of Okadaic Acid and Dinophysistoxin-1 on PDBu-Induced Down-regulation of CD4

Similar to tautomycin, okadaic acid and dinophysistoxin-1 inhibit protein phosphatases ${ }^{18)}$ and induce bleb formation of $\mathrm{K} 562 \mathrm{cells}^{4}$. As shown in Fig. 4, they also inhibited PDBu-induced down-regulation of CD4 suggesting that inhibition of protein phosphatases is involved in the inhibitory effect of tautomycin on PDBu-induced down-regulation of $\mathrm{CD} 4 . \mathrm{IC}_{50}$ of okadaic acid, dinophysistoxin-1 and tautomycin was $0.6,0.2$ and $16 \mu \mathrm{g} / \mathrm{ml}$, respectively. Although cytochalasin $\mathrm{D}$ also induced bleb formation similar to tautomycin $^{3)}$ it did not inhibit the down-regulation (data not shown).

Effects of Protein Kinase Inhibitors on PDBu-Induced Down-regulation of CD4

KT5926 $6^{19}$, an inhibitor of myosin light chain kinase was unable to inhibit PDBu-induced down-regulation of CD4. W-7 which is a calmodulin specific inhibitor ${ }^{20)}$, inhibited the down-regulation. H-7 and H-8, inhibitors of protein kinases ${ }^{21)}$, inhibited the down-regulation. The effect of H-8 was more

Fig. 3. Effects of tautomycin on re-expression of CD4.

After incubation for 1 hour in the absence or the presence of PDBu $1 \mu \mathrm{g} / \mathrm{ml}$, thymocytes were washed followed by incubation for additional 1 hour in the absence $(A, C)$ or the presence of $\mathrm{PDBu}(\mathrm{B})$, tautomycin (D), staurosporine (E) or tautomycin and staurosporine (F).

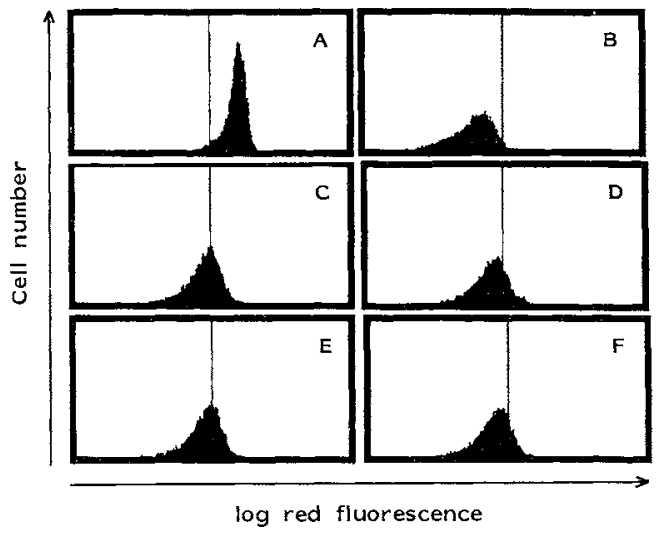

Expression of CD4 was determined as described in Materials and Methods. Concentration of agents was the same as in Fig. 2.
Fig. 4. Effects of okadaic acid and dinophysistoxin-1 on expression of $\mathrm{CD} 4$.

Thymocytes were cultured with PDBu $(100 \mathrm{ng} / \mathrm{ml})$ in the absence ( $\mathbf{A}$ ) or the presence of dinophysistoxin-1 (घ), okadaic acid ( $\square$ ) or tautomycin $(O)$. Percent CD4 ${ }^{+}$ cells was determined by a flow cytometer. $\triangle$ : percent positive cells of untreated thymocytes.

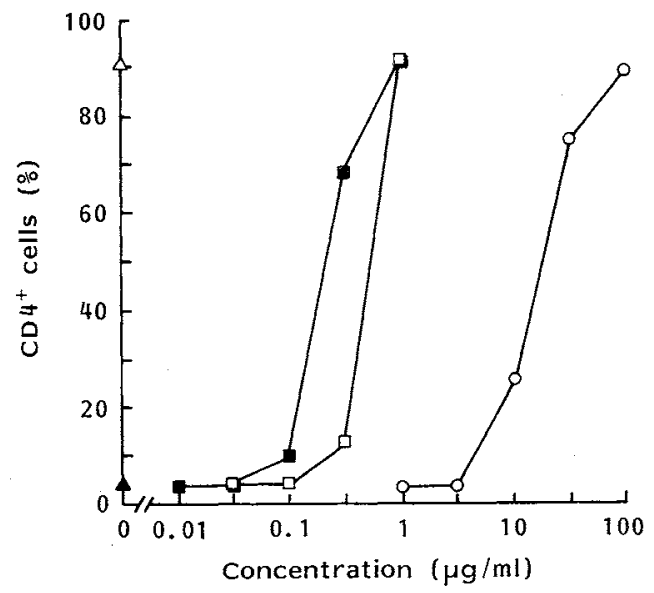


Fig. 5. Effects of kinase inhibitors on PDBu-induced down-regulation.

Thymocytes were cultured for 1 hour in the absence $(A)$ or the presence of PDBu $(1 \mu / \mathrm{ml} ; \mathrm{B} \sim \mathrm{G})$. W-7 (100 $\mu \mathrm{M} ; \mathrm{C}), \mathrm{K} 252 \mathrm{a}(\mathrm{l} \mu \mathrm{g} / \mathrm{ml} ; \mathrm{D}), \mathrm{H}-7$ ( $1 \mathrm{mM} ; \mathrm{E}), \mathrm{KT} 5926(1 \mu \mathrm{g} / \mathrm{ml} ; \mathrm{F})$, or H-8 (1 mM; G) was added to the culture.

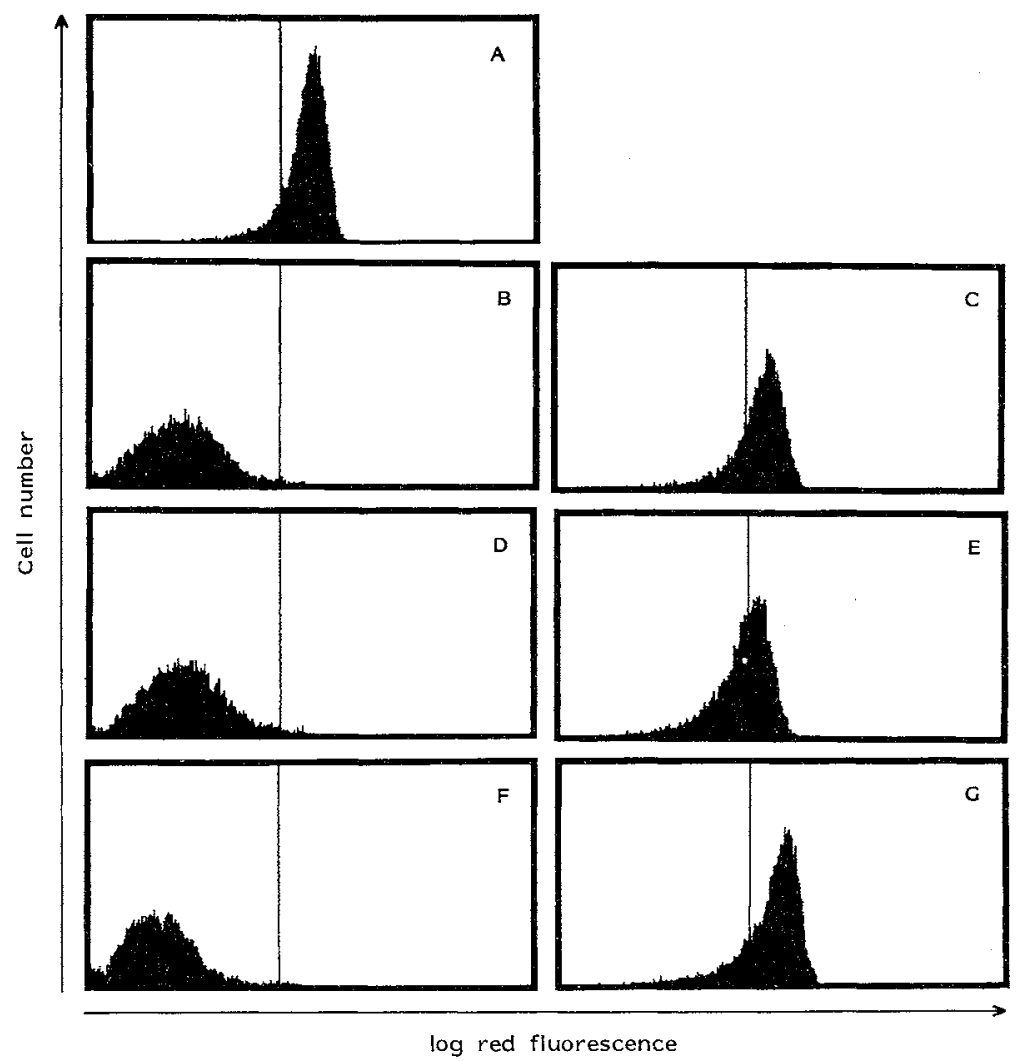

Expression of $\mathrm{CD} 4$ was determined by a flow cytometer.

significant than that of $\mathrm{H}-7$.

Although staurosporine ${ }^{14)}$ and $\mathrm{K} 252 \mathrm{a}^{22)}$ inhibited activity of multiple protein kinases, K252a, unlike staurosporine, did not inhibit the down-regulation at the concentration up to $1 \mu \mathrm{g} / \mathrm{ml}$. The same concentration of K252a completely inhibited bleb formation of K 562 cells which was induced by PDBu (data not shown). This suggests that different kinases are involved in the down-regulation and the bleb formation.

The results are presented in Fig. 5.

\section{Discussion}

In 1984 KLAUSNER et al. reported that phorbol ester, an activator of protein kinase C, induced rapid internalization of TFR, independently of its binding to the ligand ${ }^{12)}$. Since hyperphosphorylation of proteins could result from inhibition of protein phosphatases as well as from activation of protein kinases, we examined the effect of tautomycin on expression of TFR. Our results showed that tautomycin, in contrast to PDBu, induced up-regulation of TFR.

It is possible that tautomycin induced the apparent up-regulation by inhibiting internalization of TFR. This possibility was further studied with $\mathrm{CD} 4$ of thymocytes and we found that tautomycin as well as 
staurosporine did not induce up-regulation of CD4 but inhibited PDBu-induced down-regulation. However, tautomycin did not inhibit re-expression of CD4 which once disappeared after the treatment with PDBu. It is reported that it takes 48 hours for internalized CD4 to be re-expressed on the cell surface ${ }^{16)}$. In contrast, recycling time of TFR is about 10 minutes $^{23}$. Thus, it is assumed that up-regulation of tautomycin is observed only with surface antigens whose recycling time is as short as TFR. These results suggest that tautomycin inhibits endocytosis but not exocytosis of these surface antigens.

Cytochalasin D, an inhibitor of actin polymerization, did not inhibit PDBu-induced down-regulation of $\mathrm{CD} 4$ as reported previously ${ }^{24}$. Therefore, unlike bleb formation induced by tautomycin, the inhibiting effects of tautomycin on PDBu-induced down-regulation of CD4 may not be mediated through modulation of actin filaments. Okadaic acid and dinophysistoxin-1 blocked the down-regulation at lower concentration than tautomycin. The $\mathrm{IC}_{50}$ of okadaic acid against type- 1 and type- $2 \mathrm{~A}$ protein phosphatases are $224 \mathrm{~nm}$ and $10 \mathrm{~nm}$, respectively, whereas the values for tautomycin are both $32 \mathrm{~nm}$. Therefore, it is likely that type-2A phosphatase is involved in the regulation of CD4 expression.

H-8 inhibited the down-regulation more significantly than H-7. H-8 inhibits cyclic AMP dependent protein kinase (PKA), and cyclic-GMP-dependent protein kinase (PKG), more significantly than PKC, whereas $\mathrm{H}-7$ inhibits PKC more significantly ${ }^{21)}$. Thus, some kinase other than PKC may be involved in $\mathrm{PDBu}$-induced down-regulation as BiGBY et al. have already suggested ${ }^{24)}$. This interpretation was further supported by the obligation that $\mathrm{K} 252 \mathrm{a}$ did not inhibit the down-regulation. W-7, an antagonist of calmodulin, inhibited the down-regulation as BigBY et al. reported ${ }^{24)}$. We suggest that myosin light chain kinase, a calmodulin-dependent kinase, may not be related to the down-regulation because KT5926, an inhibitor of the kinase, did not affect the reaction. Further studies are required to identify the kinase involved.

Protein phosphorylation activates or inactivates various kinases and turns on/off switches of various cascades of protein phosphorylation ${ }^{25}$. Competition between staurosporine and tautomycin observed in Fig. 2 suggests that balanced reactions among protein kinases and protein phosphatases regulate the expression of surface antigens. Further study using tautomycin, specific inhibitor of protein phosphatases type-1 and $-2 \mathrm{~A}$ as well as okadaic acid ${ }^{18)}$ and calyculin $\mathrm{A}^{26)}$ will provide insights into the modulation of surface molecules by protein phosphorylation.

Acknowledgments

We thank Dr. H. FUJIKI for the generous gift of okadaic acid, Dr. H. KASE for the gift of K252a and KT5926.

This work was partly supported by the grant for "Biodesign Research Program" from RIKEN to K. NAGAI and a grant from New Energy and Industrial Technology Development Organization.

\section{References}

1) Cheng, X.-C.; T. Kihara, H. Kusakabe, J. Magae, Y. Kobayashi, R.-P. Fang, Z.-F. Ni, Y.-C. Shen, K. Ko, I. YamaguChi \& K. Isono: A new antibiotic, tautomycin. J. Antibiotics 40: 907 909, 1987

2) Ubukata, M.; X.-C. Cheng \& K. Isono: The structure of tautomycin. J. Chem. Soc. Chem. Commun. 3: 244 246, 1990

3) Magae, J.; C. Watanabe, H. Osada, X.-C. ChenG \& K. Isono: Induction of morphological change of human myeloid leukemia and activation of protein kinase $\mathrm{C}$ by a novel antibiotic, tautomycin. J. Antibiotics 41: 932 937, 1988

4) Magae, J.; H. Osada, H. Fujiki, T. C. Saido, K. SuZuki, K. Nagai, M. Yamasaki \& K. Isono: Morphological changes of human myeloid leukemia K562 cells by a protein phosphatase inhibitor, tautomycin. Proc. Jpn. Acad. Ser. B 66: 209 212, 1991

5) MacKintosh, C. \& S. KlumpP: Tautomycin from the bacterium Streptomyces verticillatus: another potent and specific inhibitor of protein phosphatases 1 and 2A. FEBS Lett. 277: 137 140, 1990

6) Hori, M.; J. MAGae, Y.-G. HAN, D. J. HARTSHORNE \& H. KARAKI: Effect of a novel protein phosphatase inhibitor, tautomycin, on smooth muscle. FEBS Lett. 285: 145 148, 1991

7) May, W. S.; N. Sahyoun, S. Jacobs, M. Wolf \& P. Cuatrecasas: Mechanism of Phorbol diester-induced regulation of surface transferrin receptor involves the action of activated protein kinase $\mathrm{C}$ and intact cytoskeleton. J. Biol. Chem. 260: 9419 9426, 1985

8) Beguinot, L; J. A. Hanover, S. Ito, N. D. Ricert, M. C. Willingham \& I. Pastan: Phorbol esters induce transient internalization without degradation of unoccupied epidermal growth factor receptors. Proc. Natl. Acad. Sci. U.S.A. $82: 2774 \sim 2778,1985$ 
9) Sutherland, D. R.; D. Delia, C. Schneider, R. A. Newman, J. Kemshead \& M. Greaves: Ubiquitous cell surface glycoprotein on tumor cells is proliferation associated receptor for transferrin. Proc. Natl. Acad. Sci. U.S.A. 78: 4515 4519, 1981

10) May, W. S.; S. Jacobs \& P. Cuatrecasas: Association of phorbol ester-induced hyperphosphorylation and reversible regulation of transferrin membrane receptors in HL60 cells. Proc. Natl. Acad. Sci. U.S.A. 81: 2016 2020, 1984

11) WATtS, C.: Rapid endocytosis of the transferrin receptor in the absence of bound transferrin. J. Cell Biol. 100: $633 \sim 637,1985$

12) Klausner, R. D.; J. Harford \& J. van Renswoude: Rapid internalization of the transferrin receptor in K562 cells is triggered by ligand binding or treatment with phorbol ester. Proc. Natl. Acad. Sci. U.S.A. 81: 3005 3009, 1984

13) Castagna, M.; Y. Takai, K. Kaibuchi, K. Sano, U. Kikkawa \& Y. Nishizuka: Direct activation of calcium-activated, phospholipid-dependent protein kinase by tumor-promoting phorbol esters. J. Biol. Chem. 257 : $7847 \sim 7851,1982$

14) Tamaoki, T.; H. Nomoto, I. Takahashi, Y. Kato, M. Morimoto \& F. Tomita: Staurosporine, a potent inhibitor of phospholipid $/ \mathrm{Ca}^{++}$dependent protein kinase. Biochem. Biophys. Res. Commun. 135: 397 402, 1986

15) SolBaCH, W.: Tumor-promoting phorbol esters selectively abrogate the expression of the T4 differentiation antigen expressed on normal and malignant (Sezary) T helper lymphocytes. J. Exp. Med. 156, 1250 1255, 1982

16) Hoxie, J. A.; D. M. Matthews, K. J. Callahan, D. L. Cassel \& R. A. Cooper: Transient modulation and internalization of T4 antigen induced by phorbol esters. J. Immunol. 137: $1194 \sim 1201,1986$

17) WANG, P. T. H.; M. BigBY \& M. S. SY: Selective down modulation of L3T4 molecules on murine thymocytes by the tumor promoter phorbol 12-myristate 13-acetate. J. Immunol. 139: $2157 \sim 2165,1987$

18) Bialojan, C. \& A. TAKAI: Inhibitory effect of a marine-sponge toxin, okadaic acid, on protein phosphatases. Biochem. J. 256: $283 \sim 290,1988$

19) NaKanishi, S.; K. Yamada, K. Iwahashi, K. Kuroda \& H. Kase: KT5926, a potent and selective inhibitor of myosin light chain kinase. Mol. Pharmacol. 37: 482 488, 1990

20) HidaKa, H.; T. YAMAKI, M. MaKa, T. YanaKa, H. Hayashi \& K. KobaYashi: Calcium-ragulated modulator protein interacting agents inhibit smooth muscle calcium-stimulated protein kinase and ATPase. Mol. Pharmacol. 17: $66 \sim 72,1980$

21) Hidaka, H.; M. INAGaKi, S. KaWAmoto \& Y. SASAKI: Isoquinolinesulfonamides, novel and potent inhibitors of cyclic nucleotide dependent protein kinase and protein kinase C. Biochemistry 23: 5036 5041, 1984

22) Kase, H.; K. Iwahashi, S. Nakanishi, Y. Matsuda, K. Yamada, M. Takahashi, C. Murakata, A. Sato \& M. KANEKO: K-252 compounds, novel and potent inhibitors of protein kinase $\mathrm{C}$ and cyclic nucleotide-dependent protein kinases. Biochem. Biophys. Res. Commun. 142: 436 440, 1987

23) Marsha, M.; J. E. Armes \& A. P. Matthews: Endocytosis and recycling of CD4. Biochem. Soc. Trans. 18: $139 \sim 143,1990$

24) Bigby, M.; P. WANG, J. F. Fierro \& M. S. Sy: Phorbol myristate acetate-induced down-modulation of CD4 is dependent on calmodulin and intracellular calcium. J. Immunol. 144: $3111 \sim 3116,1990$

25) CoHen, P.: The structure and regulation of protein phosphatases. Annu. Rev. Biochem. 58: 453 508, 1989

26) Ishihara, H.; B. L. Martin, D. L. Brautigan, H. Karaki, H. Ozaki, Y. Kato, N. Fusetani, S. Watabe, K. Hashimoto, D. Uemura \& D. J. Hartshone: Calyculin A and okadaic acid: Inhibition of protein phosphatase activity. Biochem. Biophys. Res. Commun. 159: $871 \sim 877,1989$ 